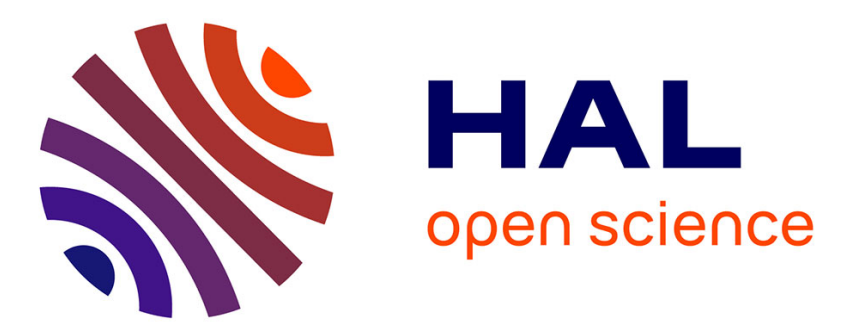

\title{
A sociology of the camps' persisting architecture. Why did Rome not put an end to expensive ethnic housing policies?
}

\author{
Gaja Maestri, Tommaso Vitale
}

\section{- To cite this version:}

Gaja Maestri, Tommaso Vitale. A sociology of the camps' persisting architecture. Why did Rome not put an end to expensive ethnic housing policies?. Manuela Mendes; Teresa Sá; João Cabral. Architecture and the Social Sciences. Inter- and Multidisciplinary Approaches between Society and Space, Springer, pp.197 - 218, 2017, 9783319534770. 10.1007/978-3-319-53477-0_13 . hal-01767033v2

\section{HAL Id: hal-01767033 \\ https://hal.science/hal-01767033v2}

Submitted on 7 Jan 2022

HAL is a multi-disciplinary open access archive for the deposit and dissemination of scientific research documents, whether they are published or not. The documents may come from teaching and research institutions in France or abroad, or from public or private research centers.
L'archive ouverte pluridisciplinaire HAL, est destinée au dépôt et à la diffusion de documents scientifiques de niveau recherche, publiés ou non, émanant des établissements d'enseignement et de recherche français ou étrangers, des laboratoires publics ou privés. 


\title{
A sociology of the camps' persisting architecture
}

\section{Why did Rome not put an end to expensive ethnic housing policies?}

\author{
Gaja Maestri (Durham University, UK) \\ Tommaso Vitale (CEE Sciences Po, Paris) \\ Please quote as:
}

Maestri, Gaja \& Tommaso Vitale (2017), 'A sociology of the camps' persisting architecture. Why did Rome not put an end to expensive ethnic housing policies?'. In Manuela Mendes, Teresa Sá \& João Cabral (eds), Architecture and the Social Sciences. Inter-and Multidisciplinary Approaches between Society and Space. London: Springer.

\begin{abstract}
Housing facilities and public shelters for Roma in Rome are expensive, highly segregated, and low quality. They have been justified on the basis of a categorization of Roma as nomads, and been challenged and criticized by Roma rights activists and international organizations. Their regulation and actor system have been object of several judicial inquiries for corruption. But they persist. Mixing different sources (semi-structured interviews, observations, and analysis of budgets) we describe the architecture of different Roma camps in Rome. We relate to four main dimensions of the relations between architecture and the space (boundaries, distribution of objects, permanence, and symbolic orders). Previous research in organizational theory has shown that architecture and interior design have a structuring and enacting power for social relations. To explain the persistence of these architecture forms, and the absence of social innovation, we look at the strategic action fields in which the camps are embedded, discussing the relevance of "invisible" relations.
\end{abstract}

Keywords: Roma; Urban Sociology; Architecture; Strategic Action Fields; Segregation; Camps.

1 The authors would like to thank Marco Cremaschi, Ulderico Daniele, Olivier Legros and Stefano Pasta for reading an early draft and for offering constructive criticism. Special thanks go also to Anne Lambert and Lydie Launay, who provided extremely useful comments during the presentation of this paper at the 2e Biennale de la sociologie de l'urbain et des territoires held in Toulouse in September 2016. 


\section{Introduction}

At the beginning of the millennium, Italy was defined "Campland" by the European Roma Rights Center (2000) because of the presence of Roma camps, an ethnically-based public housing policy financed and, in several cases, directly managed by the local government ${ }^{2}$. In the camps the Roma live in either caravans or Portakabins provided by the local municipalities, which also supply basic facilities (such as drinking water, electricity and toilet facilities) and inclusion services to the resident population. With almost one-third of the Italian Roma population ${ }^{3}$ - i.e. approximately 40,000 - living in either informal settlements or official Roma camps, the Roma are among the communities mostly affected by severe housing deprivation and segregation (Dalla Zuanna, 2013). ${ }^{4}$ Still today Italy presents an astonishing level of ethnic residential segregation in camp accommodations for Roma, based on the wrong assumptions that they are nomads (ERRC, 2013; FRA, 2009) and that these ethnic camps constitute a less expensive housing solution. In the first section we will introduce the history of Roma camps in Italy, and in the following section we will look specifically at city of Rome. Then, we will focus on the architecture of the camps, and their barriers. Coping with the multiple thresholds of these camps we will offer a sociological explanation of camps persistence, not related to the economic efficiency of the policy instruments, but on the complex action fields in which they are embedded.

\section{The Roma camps in Italy}

The journey towards the development of this policy can be traced back to the 1960s-1970s, when the advocacy action of Opera Nomadi, a pro-Roma association founded in 1965 (Bravi, 2009), increased the political attention towards the issue of the free mobility of the Roma and Travellers (Sigona, 2002). In the 1980s-1990s some Italian regions adopted regional laws with the aim of protecting Roma culture, especially their supposed nomadism. The Lazio Region was one of the first to adopted a law on the protection of Roma culture in 1985 (Regione Lazio, 1985), in the absence of any legal status of Roma as a minority (Bonetti, et al., 2011). This regional law introduced for the first time the creation of camps for nomadic Roma. However, the official camps for Roma people were introduced in the city of

2

We acknowledge the precious suggestions and criticisms by Marco Cremaschi, Stefano Pasta, Olivier Legros and Quentin Batreau.

3

The Council of Europe estimates that there are approximately 150,000 Roma in Italy, with a minimum estimate around 120,000 and a maximum one reaching 180,000 .

4

It is however important to underscore that, although the Roma people in the media are often associated to camps, ghettoes and slums, the majority of the 180,000 Roma living in Italy actually live in flats or country mansions. 
Rome only in the first half of the 1990s. An important factor that accelerated the implementation of this policy was the arrival of Roma asylum-seekers during the Yugoslav Wars. During the 1970s-1980s, Italy had already become the destination of Roma economic migrants arriving from former Yugoslavia (Pasta, Vitale et al. 2016), many of whom - despite not being "nomads" - lived in informal settlements as they intended to remain only for a short period and hence sent most of their earnings as remittances to relatives in their home country (Daniele, 2011; Monasta, 2005). However, the sudden arrival of groups of Roma during the war, the mediatization of their migration (Sigona, 2003) and the lack of recognition of the status of refugee to many of them who were without citizenships and thus obliged to find provisional and precarious shelters (ECRI, 2002; Sigona, 2015), resulted in the transformation of their presence and of the alleged increasing number of informal settlements into an "emergency" which required rapid solutions. This led local administrations to tackle the issue raised during the arrival of Roma asylum-seekers through the tool of the camp introduced by the 1985 regional law, which was though mainly concerned with the management of "nomads" rather than of asylum-seekers. Later, in 2008 Italian Government declared a state of emergency, on the basis of the law for natural catastrophes related to the "problem" of "nomad settlements" in some of the Italian metropolitan regions (Milan, Naples and Rome, followed by Turin) for special funds and regulations, on the basis of the law for natural catastrophes. Issue of nomadism were mobilized to avoid ethnic profiling, but in the following years the ethnic categorization (Roma) has substituted the behavioral one (Nomad). Scholars too have focused their attention more on slums and camps, and their regulation, than on other forms of Roma housing integration (Aguilera, Manzoni

The 2008 census in the cities of Rome, Naples, and Milan reported 12,346 Roma living in either informal settlements and camps, while official figures from the the City of Rome revealed that, in 2011 they were 7,877 only in the Italian capital city (Comune di Roma, 2011). Unofficial sources confirmed Rome as the Italian city with the highest number of Roma experiencing severe housing deprivation and residential segregation, with 11,021 Roma living in more than one hundred informal settlements (Dalla Zuanna, 2013) and 8 official camps. In the official Roma camps, the City of Rome supplies basic facilities (such as drinking water, toilets and electricity) together with a series of additional services provided by subcontractors NGOs and including internal surveillance and security as well as so-called "socio-educational" activities for the residents, namely, schooling activities for the children and (though less often) training for the adults. Besides the Roma informal settlements and official camps, in Rome there are also 11 so-called "tolerated" camps which, despite acknowledged by the municipality and provided with basic facilities, do not receive socio-educational services. As of 2013, official figures from 
the City of Rome showed approximately 4,500 Roma living in official camps, and other 1,500 living in tolerated camps (Map 1).

Map 1. The official (blue) and tolerated (orange) Roma camps and the Roma

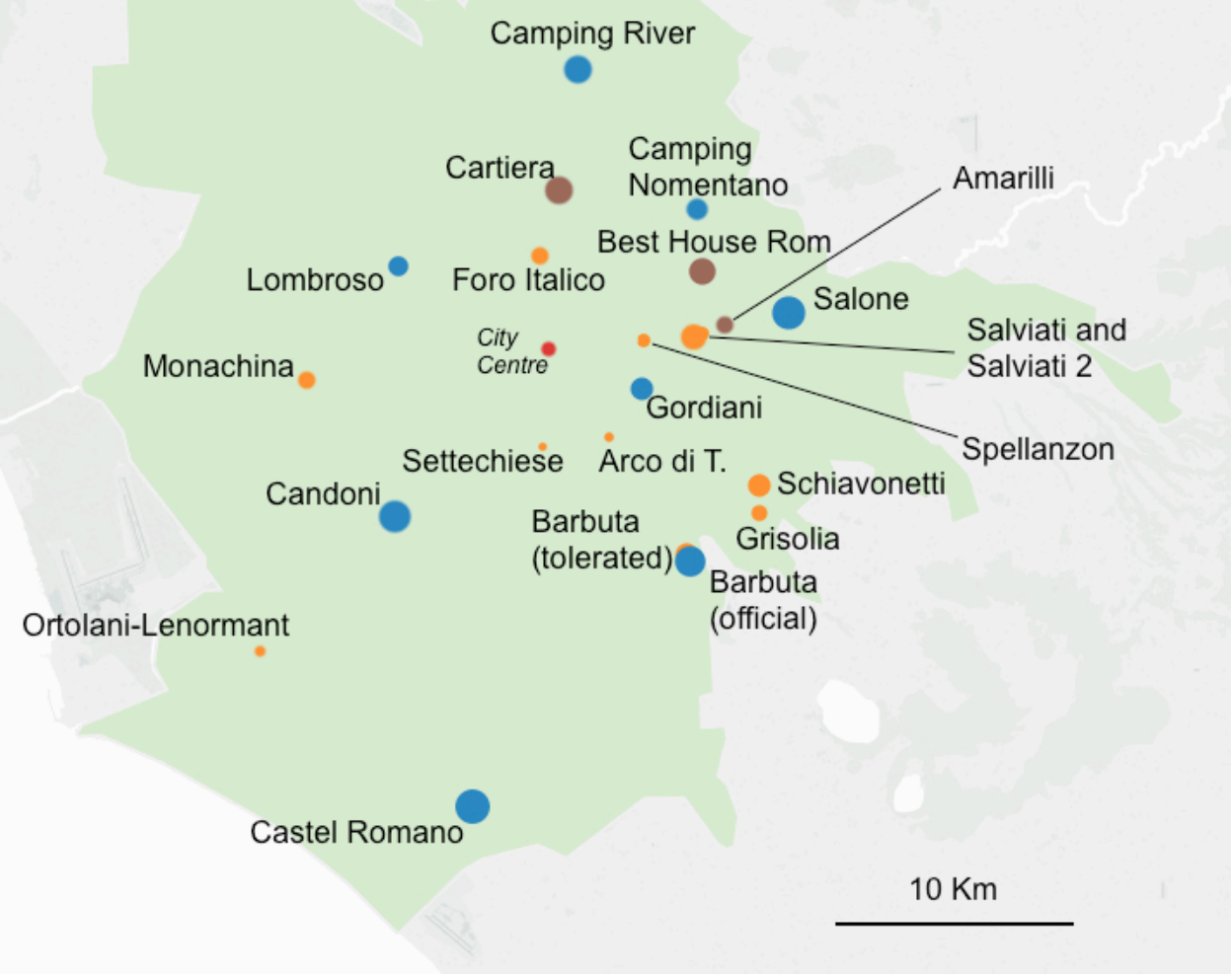

reception centers (brown).

People living in these camps experience residential segregation and severe housing deprivation, as they present low hygienic conditions, and are mainly concentrated in urban fringe, and in non-residential and isolated areas far from services and public transport. The caravans and Portakabins are often too small to accommodate the families with children (Picture 1), and also in bad conditions (Picture 2). The official camps are also often overcrowded and host more people than originally planned, with three of them housing more than five hundred people (Camping River, Candoni, La Barbuta) and other two reaching almost one thousand residents (Castel Romano and Salone). Instead of being very cheap, the system of the Roma camps has been very expensive, and since 2014 several judicial inquiries have shed lights on the direct engagement of mafia and organized crime organizations in capturing public funds for providing assistance and welfare services in the Roma camps, and the high level of corruptions of some officials, public servants and so-called Roma representatives in the sector. 
Picture 1. Picture of a caravan in Cesarina camp (picture by Gaja Maestri).
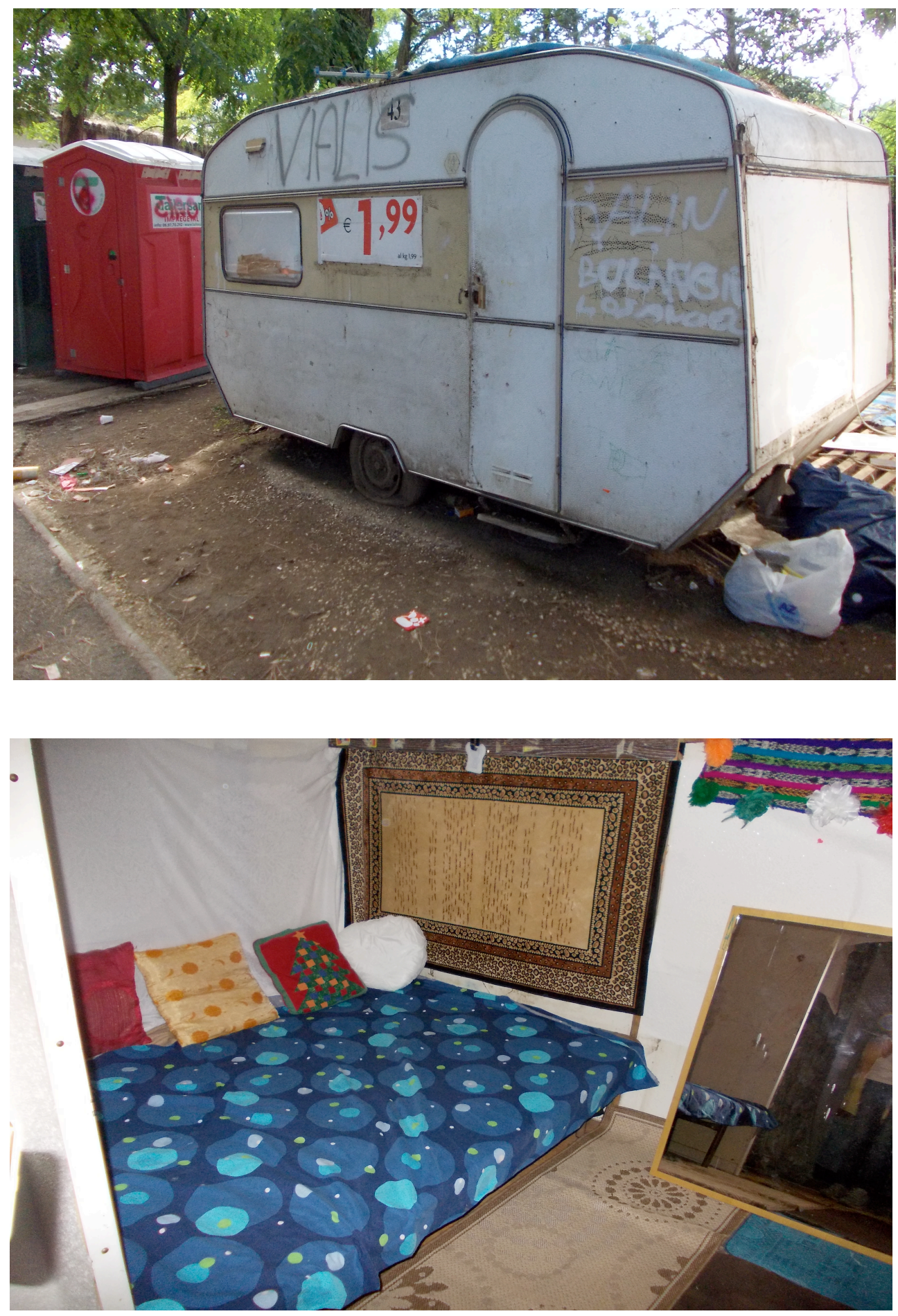

Picture 2. A bed in a caravan in Cesarina camp (by Gaja Maestri).

In the last years, the City of Rome has also created Roma reception centers where to temporary relocate Roma people evicted from informal settlements and that, like the Roma official camps, are temporary but usually located in buildings. 
Although the internal architecture of the camps is relatively flexible and is constantly changed and adapted by the residents according to their needs (Laino and Vitale 2015), the external barriers of these spaces have been barely modified throughout the last twenty years. Also internal facilities are almost the same. Even the most recent Roma reception centers simply replicate the approach shaping the Roma official camps. Instead of being easily accessible and of favoring the integration of the target population into the local society, the Roma camps and reception centers are highly sealed and separated, presenting similar features to a total institutions, and similar kind of effects on identity, social skills and strategic action on those living inside. Furthermore, inside the camps there are no cultural, social, recreational or sport-related spaces and facilities aimed at the whole citizenry and which may attract the neighbors. Those who live near the camps avoid entering them because they fear potentially negative reactions from the part of the camps' dwellers. Indeed, the architecture of the camp developed in the name of help and integration actually leads to a reduction rather than a development of social capital, destroying weak ties. Although there have been some interventions, often led by artists and architects who aimed to redesign and make the threshold of the camp more permeable, these efforts were nonetheless limited to locally based initiatives and did not introduce any substantial change in the logic of ethnic segregation of the camps.

\section{The architectural form of the Roma camps in Rome}

In this section we will describe the architecture of Roma camps emphasizing four dimensions:

a) the spatial ordering of space through the control of boundaries (i.e. the use of fences);

b) the spatial configuration of the distribution of objects (i.e.: the organization of proximity and distance;

c) the spatial organization of the camp, with its permanence (the "firmitas" in Vitruvio classical account), as opposed to the lack of robustness and good conditions of most precarious buildings (barracks and containers, as well as building for shelters);

d) the symbolic and communicative structure of such configurations, of which aesthetic values are an important yet not predominant part (with the central building devoted to social assistance, or local police office at the entry door).

These four analytical dimensions have to be considered interrelated and they allow covering the relations between architecture and space (Cremaschi, 2013). Let's start from one first example. The Salone camp is located in the eastern periphery of Rome and, with almost one thousand residents, it is 
one of the largest camps of the Italian capital city (Anzaldi and Stasolla, 2010). The plot of land was illegally occupied in 1999 by a group of Roma who set up an informal settlements, later in 2006 provided with Portakabins and basic facilities by the City of Rome (Anzaldi and Stasolla, 2010). Today the Salone camp is one of the most renown as it sadly encapsulates the main characteristics and problems of the Roma camps in Rome. It is far from services, with the closer food store at more than $3 \mathrm{~km}$ (Associazione 21 Luglio, 2014a). As several other camps, the Salone one is really overcrowded: even though the camp was originally planned to host a maximum of six hundred people, in 2010 the population peaked at 1076, while in 2013 there were still more than 900 people of Bosnian, Serbian and Romanian origins (Associazione 21 Luglio, 2014a; Anzaldi and Stasolla, 2010). There is one official entrance gate, which is patrolled $24 \mathrm{~h} / 7$ by the security guards controlling who enters. Next to the guards there is a Portakabin for the police too, which is -in fact - often empty. The camp is surrounded by a metal fence which has been, however, damaged in some parts so that the residents can more easily exit and enter the camp without passing from the main gate. The camp stretches on the left side of the main entrance, through a long straight asphalt road that cuts the camp into two specular halves with a multitude of Portakabins where the Roma live (Picture 3, Picture 4). The Portakabins are of three different dimensions: $22.50 \mathrm{~m}^{2}, 24.30 \mathrm{~m}^{2}$ and $27.60 \mathrm{~m}^{2}$ (Anzaldi and Stasolla, 2010). They have a main small door that leads to a small living room with a sofa in between two bedrooms, and a kitchen corner and they do not have an en-suite bathroom. Considering that Roma families often have many children, it is hard for a family of 6 or 8 to fit in such a small space.

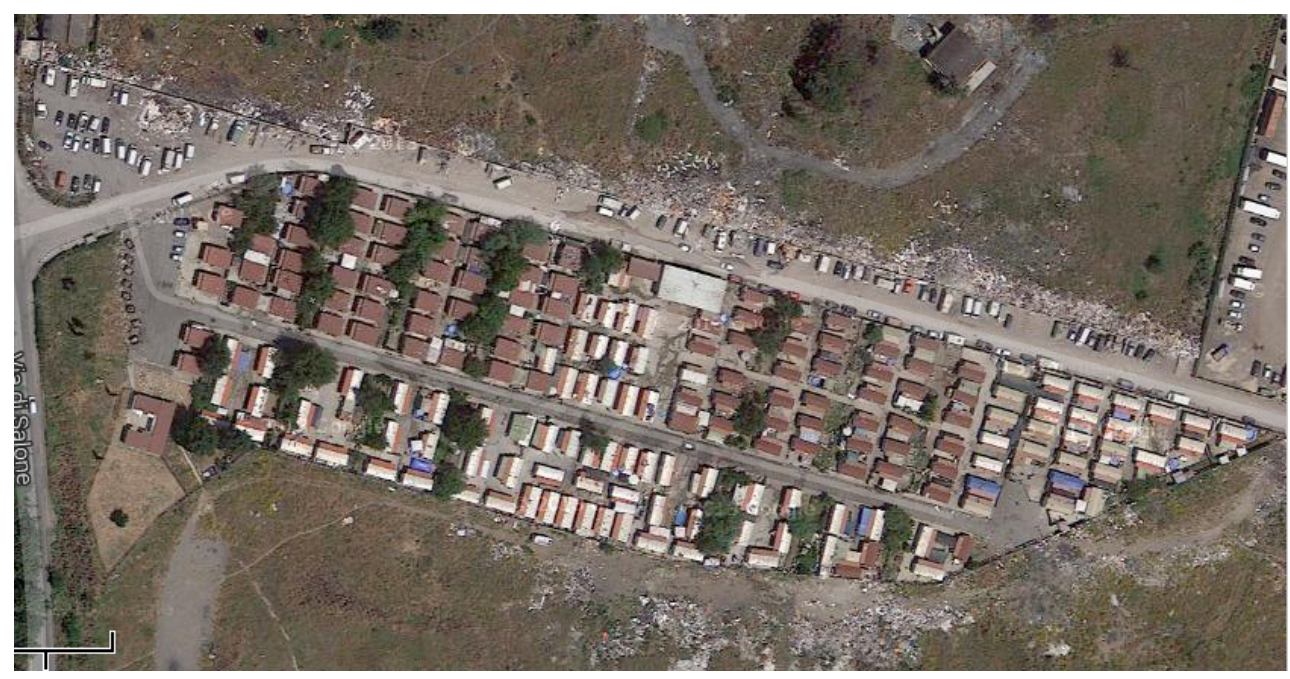

Picture 3. Satellite image of Salone camp (Imagery (C2013 DigitalGlobe). 
Picture 4. The caravans in Salone camp (reprinted with permission of Associazione 21

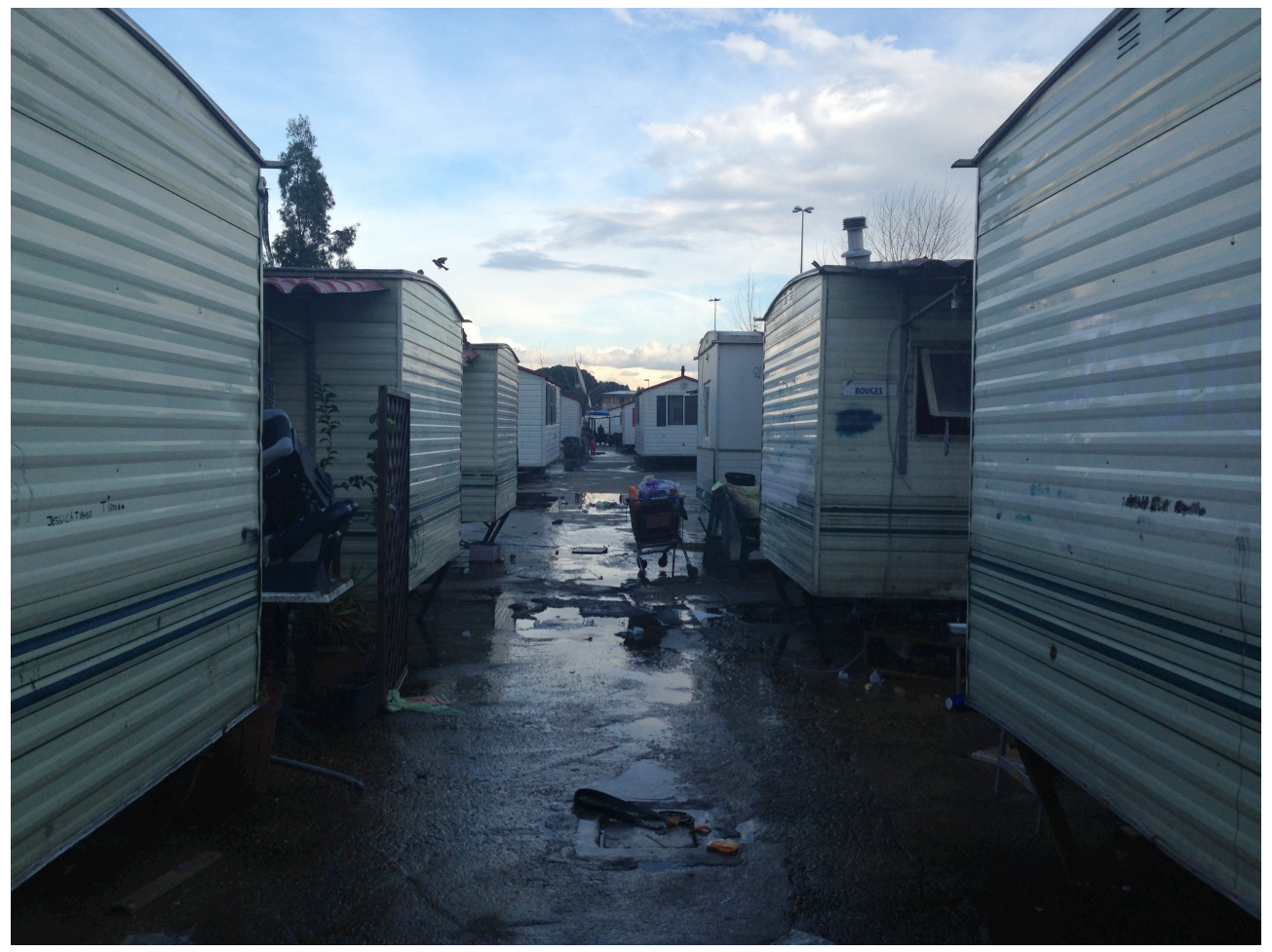

Luglio, Rome)

The Cesarina camp has been temporarily closed for refurbishment in December 2013. Situated on a natural park in the north-eastern periphery of the city, on the area of a former camping and of property of the Roma Curia, at the beginning of the 2000s it was ran by a manager who illegally rent it to hundreds of Romanian undocumented migrants for a monthly rent of approximately 200 Euros (Associazione 21 Luglio, 2012). The conditions of the camp were deplorable and the manager was later arrested for favoring undocumented migration and exploitation of labour. After dismantling the camping, in 2003 the local government opened on the same site an official camp and sub-contracted its direction to the previous arrested manager (Associazione 21 Luglio, 2012). Like in the case of the Salone camp, the main entrance gate is patrolled $24 \mathrm{~h} / 7$ by the manager who can control who access the camp. The camp is divided into two main areas, one where Romanian Roma live in caravans and Portakabins and another where Bosnian and Montenegrin Roma live in mobile housing units. In the Cesarina camp there were more than 150 Roma living in a total of 40 old Portakabins and caravans, with $13 \mathrm{~m}^{2}$ for more than 4 people on average (Associazione 21 Luglio, 2012). The caravans were especially unsuitable to accommodate a family because they were old and during winter really cold, and also because some of them lacked electricity. Toilet facilities are insufficient for the population, with only 8 toilets and 8 showers which presented really low hygienic conditions. For this reason the City of 
Rome provided additional chemical bath (Picture 5), which however did not solve the lack of hygiene in the camp, which was temporarily closed because of this lack of safety and security standards and the residents relocated to the Roma reception centre Best House Rom.

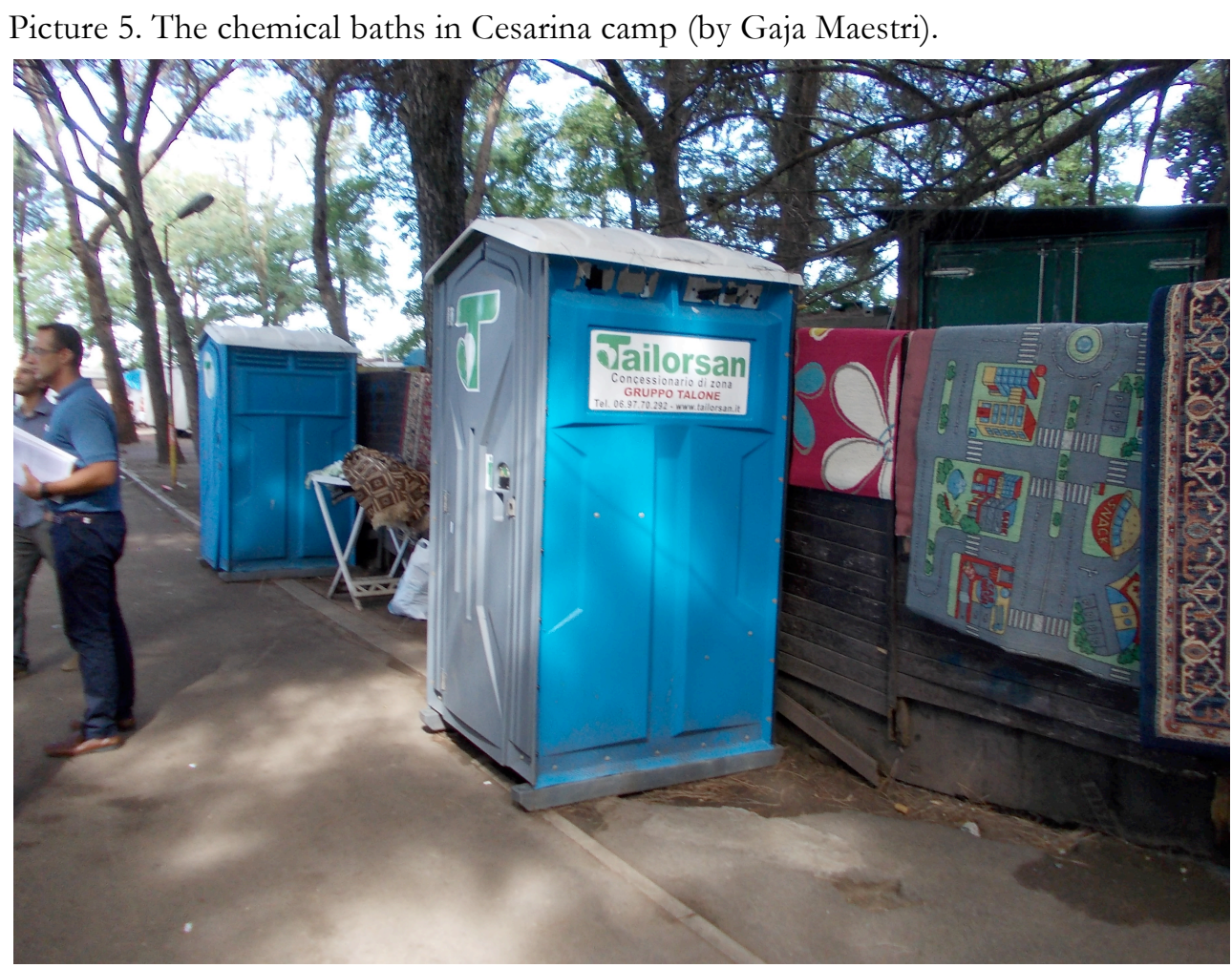

The case of the Roma centre Best House Rom became infamously known for epitomizing the system of high public expenditure for low quality housing standards (Picture 6). The centre is located in the eastern periphery of Rome, was opened in 2012 and today host 359 Bosnian and Romanian Roma (72 families). The Associazione 21 Luglio revealed the shameful living conditions of this Roma center: the building of the centre was actually inhabitable, being designated as depository. Nonetheless families were relocated there, being assigned one bedroom of $12 \mathrm{~m}^{2}$ each (i.e. about $2.5 \mathrm{~m}^{2}$ for each person, below the legal $12 \mathrm{~m}^{2}$ indicated by the Lazio Region), with no windows and no kitchen facilities despite the lack of full catering (Associazione 21 Luglio, 2014b). These were the conditions offered for more than $2 \mathrm{ml}$ Euros, i.e. 7,796 Euros per capita in 2014 (over 38 thousand Euros per family in 2014, for a total of 150,017 Euros since its inauguration in 2012) (Table 1). The money invested in the centre exposed the local government to criticisms for an unclear way of managing. Indeed, even though the 92.8 percent of outlays went into the maintenance of the building (to the detriment of schooling and social inclusion services), the conditions of the centre were unsuitable to host families for a long period. 
Table 1. Expenditure for Roma reception centers, Rome 2014.

\begin{tabular}{|l|c|c|c|}
\hline Reception center & $\begin{array}{c}\text { Number of } \\
\text { families }\end{array}$ & $\begin{array}{c}\text { Total expenditure } \\
\text { (in Euros) }\end{array}$ & $\begin{array}{c}\text { Annual expenditure } \\
\text { per family (in Euros) }\end{array}$ \\
\hline Cartiera & 102 & $2,073,724$ & 20,331 \\
\hline Best House Rom & 72 & $2,798,878$ & 38,873 \\
\hline Amarilli street & 20 & $1,394,469$ & 69,723 \\
\hline San Cipirello street & 10 & 253,751 & 25,375 \\
\hline Torre Morena street & 9 & 497,816 & 55,313 \\
\hline Toraldo street & 21 & 494,185 & 23,533 \\
\hline Ex Fiera di Roma & 8 & 185,017 & 23,127 \\
\hline TOTAL & $\mathbf{2 4 2}$ & $\mathbf{8 , 0 5 3 , 5 4 4}$ & $\mathbf{3 3 , 2 7 9}$ \\
\hline
\end{tabular}

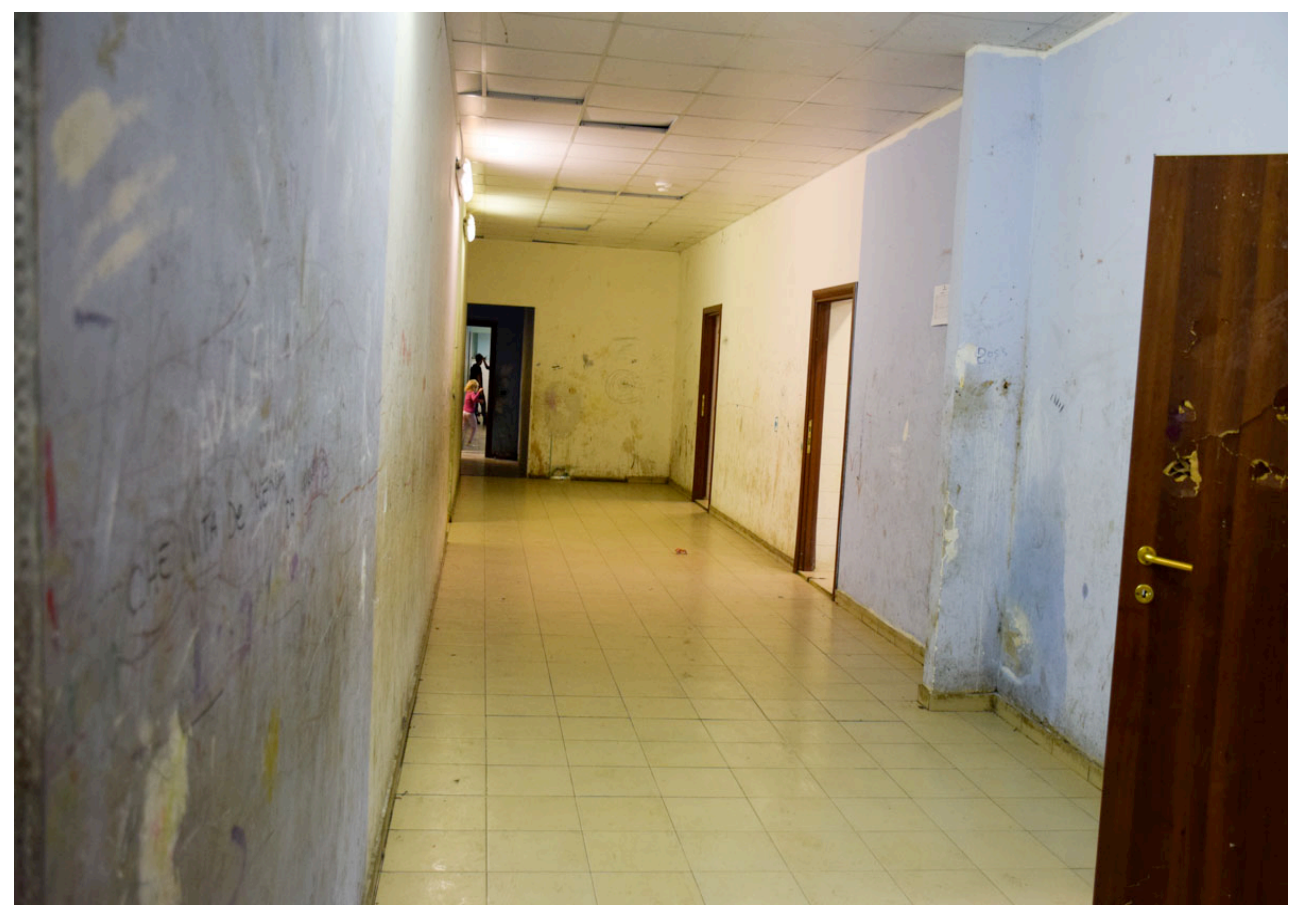

Source: Associazione 21 luglio, 2015.

Picture 6. A corridor in the Best House Rom centre (reprinted with permission of Associazione 21 Luglio, Rome) 
The Roma reception centre Cartiera was opened in 2009 and it is currently in the process of being closed, although there are protests against its closing because no alternative relocation has been yet offered to its residents. As of today there are approximately 380 people, mainly Bosnian, Montenegrin and Romanian Roma (Associazione 21 Luglio, 2015). The Cartiera is an old paper factory located in the northern part of Rome, in a building with a tall and heavy gate patrolled 24/7 (Picture 7). Therefore, entering without a permission or without being seen by some of the guards is virtually impossible. The social life of the centre main occur in the backyard of the building, adjacent to a municipal waste disposal area which strongly affect the air of the building. In the backyard there are some kitchen corners where groups of women can cook because inside there are no kitchen facilities (the centre was originally planned as catered accommodation but it was then serving only one meal a day). The residents sleep in the internal part of the factory, which is not equipped with a series of fitting rooms where the families can sleep. Before, they were sleeping together in the main hall of the factory, using some bedsheets to symbolically divide the space and to seek privacy. After the Associazione 21 Luglio complained to the city about the lack of privacy, the fitting rooms were provided yet they are not big enough for a family of 4 or 5 people as they are only $12 \mathrm{~m}^{2}$ each (Associazione 21 Luglio, 2015). With only one toilet for 20 guests on average, toilet facilities are insufficient for the residents, and there is only one room for social activities which only has one television and video games. As in the case of the Best House Rom, with 600 Euros spent per capita each month (over 20 thousand Euros per family in 2013 and approximately 231 thousand Euros per family since the opening of the center), the living conditions could be far better.

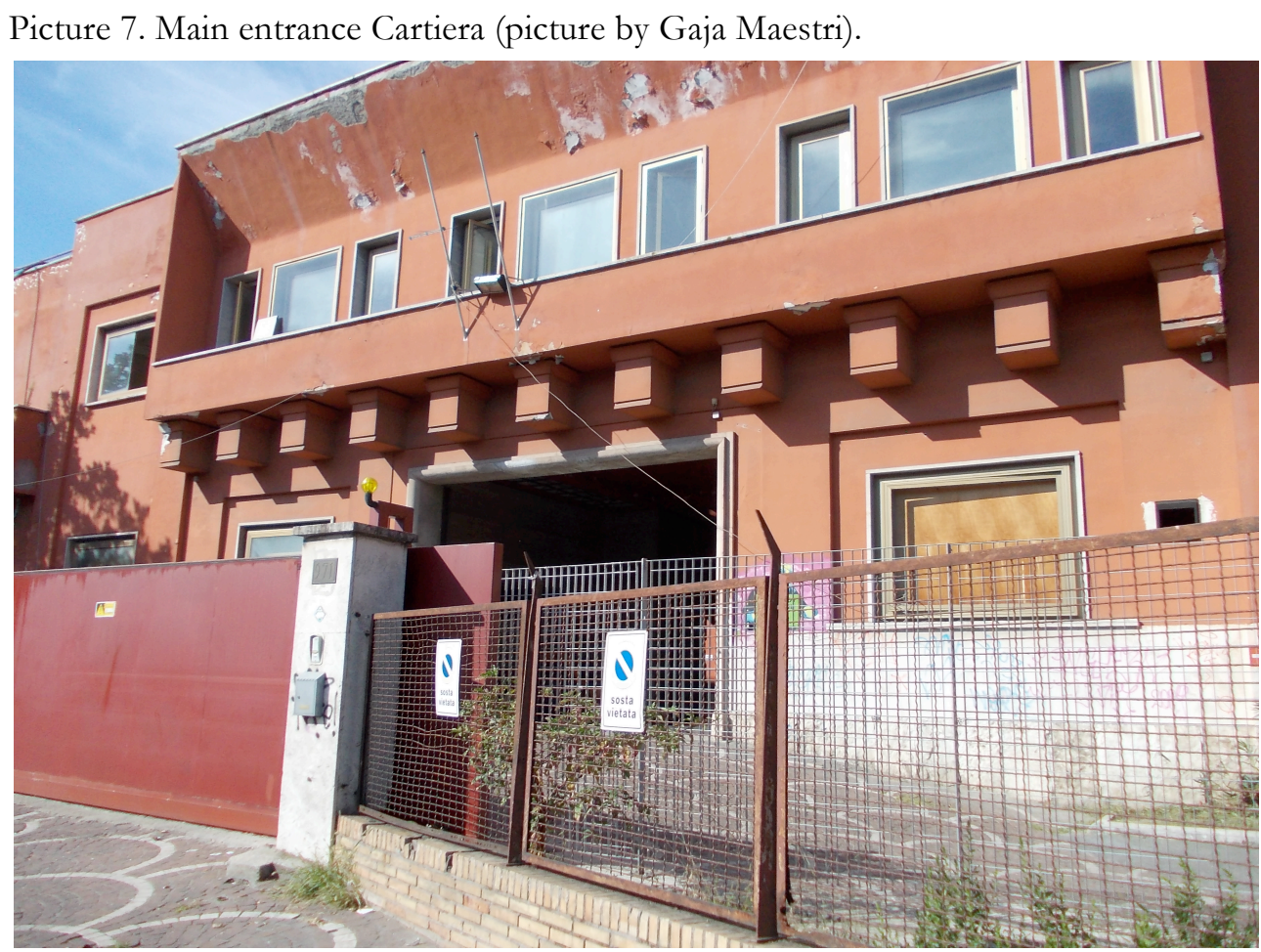




\section{The power relations behind spatial planning}

The four examples illustrated in the previous section perfectly represent the architectural features of the rest of the Roma official camps and reception centre in the City of Rome. Since the second half of the 1990s the City of Rome, during both left-wing and right-wing administrations, created new Roma camps with the same design, even though this policy is increasingly costly. In addition to this, the deplorable conditions of the Roma camps have negative effects on the real estate market in the neighborhoods where they are located, increasing even further the burden on Roman citizens. From 2005 to 2011 the city of Rome spent a total of 70 million Euros for Roma-related policies and projects (Berenice, Compare, Lunaria and OsservAzione, 2013). The expenses almost doubled in 2009 after the declaration of the state of emergency for the "Nomad problem", during which Rome received a total of 32 million Euros to implement the Nomad Plan (Stasolla, 2012). These financial resources are, however, largely ineffective and disproportionate, as revealed by the conditions of the camps just described (Table 2). In fact, as demonstrated by a series of associations it is possible to achieve better housing condition at a same price.

Table 2. Expenditure for Roma Camps, Rome 2013.

\begin{tabular}{|l|c|c|c|}
\hline \multicolumn{1}{|c|}{ Roma camp } & $\begin{array}{c}\text { Number of } \\
\text { families }\end{array}$ & $\begin{array}{c}\text { Total expenditure } \\
\text { (in Euros) }\end{array}$ & $\begin{array}{c}\text { Annual expenditure } \\
\text { per family (in Euros) }\end{array}$ \\
\hline Lombroso & 30 & 344,616 & 11,487 \\
\hline Candoni & 164 & $2,393,699$ & 14,595 \\
\hline Gordiani & 51 & 691,121 & 13,551 \\
\hline Cesarina & 34 & 607,605 & 17,871 \\
\hline Camping River & 105 & $2,204,363$ & 20,994 \\
\hline Castel Romano & 198 & $5,354,788$ & 27,044 \\
\hline Salone & 180 & $2,891,198$ & 16,062 \\
\hline La Barbuta & 116 & $1,717,004$ & 14,802 \\
\hline TOTAL & $\mathbf{8 7 8}$ & $\mathbf{1 6 , 2 0 4 , 3 9 4}$ & 18,456 \\
\hline
\end{tabular}

Source: Associazione 21 luglio 2014.

A project developed by Stalker, a group of architects based in Rome, showed that the same amount of money could correspond to higher housing standards. The project, called Savorengo Ker (meaning 
"everyone's house" in Romani language) was developed in collaboration with the residents of the former informal settlement Casilino 900 in 2008. The architect designed and built the house together with the people living in Casilino 900, and finally developed a two-storey wooden house of $70 \mathrm{~m}^{2}$ for a total cost of 24,000 Euros (Muzzonigro, 2011). The cost is the same as for the Portakabins used in the camps, but it is at least three times bigger and meeting the needs of the families, also involving them in the construction works and therefore increasing their attachment to the house. Also the Associazione 21 Luglio has revealed that it is possible to develop more inclusive forms of housing with less money. For instance, while the creation of the camp La Barbuta in Rome costed more than 80,000 Euros for each family, a self-building project costed approximately 50,000 Euros, and a renovation project drastically reduced the expenses per families to 10,000 Euros (Associazione 21 Luglio, 2014a). These projects denounce the ineffective and unsustainable costs of the Roma camps, showing how for less money there could be more inclusive and better housing solutions. Yet, the Roma camps are still highly isolated (Table 3) and their architecture have persisted until today, revealing how their architectural form is not the result of a technical and rational planning which aims to maximize costs and quality, but the product of more intricate and political mechanisms which perpetuates this ineffective and segregating spaces.

Table 3. Roma Camp in Rome, 2014.

\begin{tabular}{|l|c|c|c|}
\hline \multicolumn{1}{|c|}{ Roma camp } & Starting year & $\begin{array}{r}\text { Distance from the } \\
\text { city center (in Km) }\end{array}$ & $\begin{array}{c}\text { Number of } \\
\text { inhabitants }\end{array}$ \\
\hline Lombroso & 2000 & 12.3 & 190 \\
\hline Candoni & 2000 & 12.4 & 820 \\
\hline Gordiani & 2002 & 7.3 & 253 \\
\hline Cesarina & 2003 & 12.7 & 172 \\
\hline Camping River & 2005 & 18.0 & 611 \\
\hline Castel Romano & 2005 & 31.7 & 937 \\
\hline Salone & 2006 & 16.4 & 900 \\
\hline La Barbuta & 2012 & 14.5 & 4,494 \\
\hline TOTAL & - & 15.67 (average) & 611 \\
\hline
\end{tabular}

Source: Associazione 21 luglio, 2013.

This chapter investigates this persistence of the architectural forms of the Roma camps and seeks to understand what are the political mechanisms that hinder its change. We will address this question by 
analyzing the City of Rome. As illustrated above, the Italian capital city hosts the largest Romani population in Roma camps and reception centers, for which it has invested large financial resources nevertheless obtaining poor results from an architectural point of view. It constitutes, therefore, an important entry point into politics behind the spatial planning of the camps. However, the extant literature on the Roma camps' architecture does not provide a satisfying answer to this question.

Sibley (1981) argues that the architecture of the Roma camps reflects an attempt of ordering the Roma population which is "perceived as disorderly and threatening" (p.38). The design and disposition of caravans inside a camp reflects the desire of order which is seen as lacking in the Roma communities. The idea that the design of the Roma camps reflects a gaze imposed by the "majoritarian society" (as if it were a metaphysical unity able to express one vision and a unique representation) is shared by other scholars. Features of the Roma camps like the presence of caravans instead of stable housing units and the temporariness of the stay mirror the assumption that the Roma have a mobile way of living, thus "nomadizing" them as an effect (van Baar, 2011). At the same time, nomadism as concept shaping the policies targeting the Roma also works as a discourse justifying the actual rejection of these groups, confined in spaces shaped by the contempt towards them (Brunello, 1996). The refusal of this population translates into space, being for instance located in degraded peripheries of the city (Però, 1999). While the space of the camp has been observed as the ultimate form of imposed segregation and containment of internal outsiders, there has been also growing attention towards the agency of the camps' residents, who have reshaped the context in which they live, also strategically (Vitale, Membretti, 2013; see also Cremaschi, Fioretti, 2016).

Even though the literature on the Roma camps has widely discussed both the role of racism and discrimination in the formation of these spaces and the resistance emerged in these segregated spaces, it has nonetheless given less attention to the interaction between these two levels, thus limiting the understanding of the persistence of this form of segregation. We therefore propose a sociological reading of the architecture of the camps which focuses on the relationships between institutional matrixes and the social bases of regulations (Bagnasco 2016). While, on the one hand, we look at the norms and incentives that regulate the allocation of resources in the reproduction of the Roma camps, as well as their physical settings, on the other, we connect the analysis of the institutional matrix with an inquiry into the social bases of the interest groups and collective actors that profit from the current configuration of the Roma camps. Within this classical Weberian sociological approach we look at current developments in sociological theory that may help us understand the persistence and change of an architectural form. Fligstein and McAdam (2012), dissatisfied with the lack of a sociological 
framework that could account for the relation between institutions and the individuals, suggest a formalized theory on collective action. The core concept of this theory is "strategic action fields" (SAFs), which can be defined as "fundamental units of collective action in society" (Fligstein and McAdam, 2012, p.9) working as a meso-level social order with an institutional matrix of rules and incentives, as well as a structured configuration of relations among actors. The constant interaction between actors (either individual or collective) with different degrees of power makes the SAFs more or less stable. Therefore, unlike in functionalists accounts, change is conceived of as constitutive aspects of a SAFs and not reduced to something exogenous, generated outside of it. However, the sheer presence of groups with different interest and strategies does not necessarily translate into change, but the stability of an array of different aspects, such as: the presence of formal rule protecting the power of the so-called "incumbent" actors, a legitimate "governance unit", the lack of external allies for "challengers" and a higher connectedness with other SAFs are all aspects that make the SAFs more stable.

Fligstein and McAdam's analytical framework can prove fruitful to avoid a functionalist interpretation, characterizing most of the literature on camps. In fact, to conceive of the camps as a SAF enables us to focus on the dynamics that led "incumbent" actors promoting an ineffective and highly isolating architecture to maintain their power against "challengers" that advocate more inclusive and economically sustainable architectural solutions. The question "what made this architectural form chronically persistent?" cannot be answered by a tautological response about the camps being functional to make the Roma invisible or to re-educate them. Obviously, every architecture plays a function. However, the answer should be able to explain why and how a specific architecture - with all its functions - persists despite economic and social inefficiencies and failures. Thus, the research question can be re-phrased as follows: "why there have not been actions aimed at the innovation and change of the barriers and architecture of these spaces?" Explaining the stability of power of actors supporting the current Roma camps - despite the presence of available and cheaper alternatives implies necessarily accounting for the lack of power of those opposing this policy. These reflections arising from Fligstein and McAdam's work can be useful to shed light on the role of the architecture of the camps in bolstering the stability of this SAF. We indeed argue that the architecture of the camps works as a mechanism that hinders change because it facilitates the isolation of the Roma, the control of their contact with the outside, the steering of their potential dissent and of their official political representatives, as well as the lessening of the legitimacy of alternative policy instruments (Halpern, et al., 2014). In the following sections we will illustrate the effects of the architectural form of the camp 
and, by referring to Fligstein and McAdam's theory, what are the mechanisms that enable this architectural forms and its effects to persist.

\section{Roma camps architectural form and its effects}

The Roma camps, with their highly sealed barriers and the bulky presence of third-sector organizations involved in the management of security services and activities with the residents, are spaces that contain social relations and isolate the voice of the Roma and repress the emergence of dissent towards this form of segregation. Furthermore, even the tools that throughout the years have been presented as enabling the political participation and representation of the camps' residents have failed to do so and have actually reinforced the segregation and confinement of those criticizing the policy of the Roma camps.

As illustrated earlier in the chapter, the associations played a crucial role in the Roma camps since the inception of this policy in the early 1990s. Indeed, private actors historically had an important role in the planning of territorial and social policies in Italy (Polizzi, Tajani and Vitale, 2013). The presence of sub-contracting associations in the camps have been justified by a humanitarian intervention, aimed at the inclusion of the Roma. However, instead of increasing their inclusion, by isolating them and by mediating their claims or complaints it has perpetuated their exclusion, thus favoring a small elite of Roma residents complying with the segregating policy of the camps and impeding to the actors challenging it to establish contacts with the rest of the residents (Daniele, 2011). The recent police enquiry Mafia Capitale officially uncovered the detrimental effects of the involvement of self-styled proRoma associations in the management of the camp. In 2014, the policy unveiled an intricate corrupted system through which politicians, officials, members of third sector associations and of criminal organizations rigged the bids to select subcontractors for the management and provision of services in the Roma camps and refugee reception centers and then appointed specific associations which would in turn support those politicians both politically and economically. However, rather than a rupture with how things were managed before, this corrupted system led to an exacerbation of the already foggy way of managing the Roma camps through the manipulation of the main contractual devices and standards of the tenders for service delivery of contracting out NGOs. And it led to new judicial inquiries in 2015 and 2016.

The mediation carried out by the associations in the camps occurs, first, by monopolizing the access to the camps and reducing the possibility of the residents to get in touch with associations that are not 
officially working there and, second, by steering the mobilization of the residents and by filtering their contacts with the outside. Both these two dynamics are enabled by the material and architectural structure of the camps and reception centers, which are difficultly accessible and constantly (though to different degrees) controlled by sub-contracting associations. The Cartiera centre epitomizes the power of managing association, both in steering and filtering residents mobilization and complaints, but also their power in managing the relationship between the outside and the inside of the camp. It is indeed virtually impossible to access the centre without passing through the main gate's control, and subsequently to visit the centre autonomously. During two visits to this centre, the workers of the managing associations kindly welcomed us and presented the centre, explaining how it worked and introducing us to some of the residents. We were also offered the support of a linguistic mediator working in the camp. However, the constant presence of the managing association's members and operators resulted in a filter to interviews and to direct conversations with residents, mainly those who were criticizing the situation, while contacts with those more positive about the situation were facilitated. For instance, while we were introduced to a Roma resident of the centre who also works for the managing association as responsible for the children's sport activities, other residents who raised some critical issues regarding the centre were quickly dismissed by the operators and managers. The presence of sub-contracting associations turns from inclusion into control, which hinders contacts between the residents and actors opposing this policy. For example, also in the Cesarina camp the main entrance was constantly patrolled by the manager. When we visited this camp with a member of an association widely renown for its critical stance on the Roma camps, this person made up a fake name to access the camp in order not to be recognized and to enter the camp. However effective the control of the camps is, the attitude of the managing associations is to make the exchange between the inside and the outside of the camp more difficult instead of facilitating it. This enforced isolation is enabled by the presence of gates, walls and metal fences that buttress the power of the gatekeepers.

Furthermore, the isolation of the residents is further exacerbated by the formation of a small Roma elite that complies with the policy of the Roma camp and that contributes to silencing the potential dissent emerging among its residents. Although essentialist and culturalist interpretations depict the Roma as a sort of backward individualistic "tribe" supposedly unable to organize collective action and to fight for their rights, we emphasize that strategic collective action is a social skill, i.e. it is either produced or destroyed within the very action fields where people live and establish relations. In our case study, the reduction of the Roma's capacity of collective action occurred through the means of participatory instruments. Paradoxically as it may seem, action fields and social skills are indeed 
structured by the implementation of policy instruments, and not by policy goals or explicit philosophies (Boisseuil, 2016).

To understand social skills as embedded in action fields and affected by policy instrumentation enables us to plug a concrete participatory dynamic into our analysis. The isolation and the concerns about the actual freedom of the residents living in the camps, as well as the absence of a direct voice of Roma within the governance of Roma camps (Vitale, Boschetti 2011), led several pro-Roma advocacy group to demand an improvement in the policy instruments aimed at a more active political participation of the Roma to the design of the policy of the camps. For this reasons, past local administrations, both left-wind and right-wing, have introduced in policies and regulations of the camps the presence of Roma associations and representatives. Yet, instead of de-segregating the camps by widening the participation its residents, the co-optation and officialization of a Roma leadership - though relatively unimplemented - actually reinforced the isolating tendencies of the camps, thus reducing collective action as a social skill shared by the camps' dwellers. Indeed, instead of promoting a form of political participation and representation beyond the boundaries of the camps, the camp was taken as the community of reference and therefore the representative chosen among the residents, hence reproducing the enclosed character of this policy. Moreover, this Roma elite, that in different ways control the community living in the camps, has been exploited by mayors and politicians to show their commitment towards the involvement or Roma communities while actually securing the stability of the policy of the camp.

\section{From material barriers to the multiple thresholds of the camp: a regime of action}

What our empirical research highlights is that the architectural form and the quality of the space of the camps contain the Roma, making them invisible, weakening their social skills for collective action and coalition-making, and hiding underpinning social conflicts. The Roma camps are places of tolerance, where a certain undesirable population is contained and some deviant behavior is allowed, to the extent that it does not become visible outside the camps, spreading into the city._Indeed, the architectural barriers of the camps cannot be treated as a mere material feature of this space, but also entails an array of different thresholds with different social effects. From a sociological point of view, the architecture and geographical placement of the camps also produces a plurality of social boundaries that stretches beyond the physical fencing in of the Roma and strongly orient the actors involved in this policy and affect their way of thinking and acting. Studies on urban segregation have shown that the mechanisms 
presiding the genesis of radical residential segregation are not the same mechanisms shaping the maintenance of this extreme segregation (Vitale, 2009; Sampson, 2012). Our research shows that this is true for total institutions as well as for the Roma camps, in terms of stigma, mechanisms of internal economic exchange, and also some kind of process of identity adaptation and skills formation (Vitale, 2010). Employing Fligstein and McAdam's theory on the SAFs enables us to shed light on three main mechanisms at work in the maintenance of the social effects of the architectural design of the camps. The first concerns the threshold between the inside and the outside of the camps as a clear marker of the power relations characterizing the camp, the second is about the co-optation of the Roma residents and elites and the third regards the highly permeable threshold between the camp and other SAFs which increase its stability.

Fligstein and McAdam (2011) argues that, in stable SAFs, "[t]he rules of the game will be known" (p.14). Despite the policy of the Roma camps is characterized by strong ambiguity, mainly with regard to its origins, goals and regulatory framework (Daniele, 2011; Sigona, 2011), the camps' barriers translate into a multiplicity of threshold drawing clear distinctions between the inside and the outside, between the controllers and the controlled, the helpers and the helped ones, with clear and distinct symbolic and material incentives to the service providers and the target population. On the other hand, despite these clear distinctions, the ethnic categorization underpinning this separation is naturalized and become invisible, as if it were impossible to conceive these architectural spaces differently, with the result that all the alternatives lose legitimacy and are removed from the governing agenda. Thus, this spatial design constitutes at the same time a rigid "regime of action" (Boltanski and Thévenot 2006; Vitale and Claps 2010), i.e. a modality of public action, and a tool of domination which reproduces power asymmetries, becoming an institutional matrix according to which the actors involved in it act, leaving no space for critical collective reflections. Indeed in the camp, while the residents are separate from the world outside the camps and therefore forcibly enact their segregation, the workers of subcontracting associations actually lose their autonomy and the capacity to propose alternatives, thus reproducing what is imposed by that specific architectural form (Clough Marinaro and Daniele, 2014). As a consequence, the access to a camp is not only the access to a local welfare service for housing emergency, but increasingly becomes the access to one architectural space which produces disempowerment and chronicity: a total institution that entraps its residents and adapt their preferences. Architecture has, thus, worked as a stabilizing aspects of this SAFs, increasing the power of control of incumbent actors, and reducing the power of (even potential) opponents and claimers of alternative housing opportunities. 
Furthermore, not only have the camps enabled the silencing of the Roma voice, but the spatial confinement into a sealed camp allowed the dominant actors to develop strategies of co-optation when the power of challengers was rising. Co-optation is, indeed, one of the main strategies employed by dominant groups to preserve their position in the SAFs (Fligstein and McAdam (2011). As mentioned above, the growing concern regarding the isolation and lack of participation of the camps' residents led the local administrations of Rome to adopt measures to formally include Roma associations and representatives into the decision-making process and planning of the services for the Roma population, including the camps. However, instead of effectively implementing processes of bottom-up participation and to include the voice of the Roma, the tools developed - i.e. the inclusion of Roma associations in board meetings, the appointment of a mayor's counsellor and the election of camps' representatives - actually further sustained the exclusion of the Roma. Participation can indeed be used instrumentally and "it can also be exclusionary and perpetuate inequality" (Silver, Scott and Kazepov, 2010, p.473).

Finally, the camps and their architecture have persisted because they are strongly connected to a series of other SAFs and, as Fligstein and McAdam (2011) argue "[t] he more connected an SAFs is to other SAFs, the more stable that SAF is likely to be" (p.17). Indeed, not all relevant structuring mechanisms are related to the endogenous dynamics of the specific policy sector. The recent Mafia Capitale police enquiry revealed the system of the Roma camps being tightly connected to the political ones and also to criminal organizations. Instead of working as a welfare service for people experiencing severe housing deprivation, the main goal of the actors planning and implementing the camps became to sustain their private political and economic interests to the actual detriment of the people in needs and officially the beneficiary of this housing policy. Employing the categorization of the field environment proposed by Fligstein and McAdam, the corrupted system constituted a proximate field which strongly affected the persistence of the Roma camps. Therefore, when challengers aim their criticisms at the Roma camps by denouncing their deplorable conditions, its excessive costs, their discriminatory character and the lack of achievement of the objective for which they were officially established at the beginning of the 1990s, the SAF of the Roma camp remains stable because the corrupted system sustaining it was not targeted by these attacks. Moreover, the SAF of the Roma camp is also strictly connected to the political system because the Roma camps constitute a political issue that provoke strong reactions, both among politicians and constituencies of all political colors. The widespread stigmatization of the Roma people makes it highly unpopular to support the inclusion of the Roma and also the change in current policies and expenses, mainly in a period of economic recession (Maestri, 2014). Yet, economic rationality in times of austerity could have implied a radical change in the allocation of money and in the selection of 
the appropriate policy instruments. We cannot understand the logic and the dynamic of consensus if we remain anchored to a decontextualized form of economic rationality. On the contrary, our analysis of the SAF shows how, in order not to lose support, politicians opt not to change the current architecture of the Roma camps as a strategy of "blame avoidance" (Weaver, 1986). Indeed, as it is often the case for urban policies for the poor, local governments seek to prevent the raising of potentially dangerous issues by steering the scope of the political process towards only those issues which are presumably innocuous, thus limiting the decision-making to relatively non-controversial subjects and influencing community values, political procedures and rituals too (Bachrach and Baratz, 1970).

The Roma camps are often mobilized for justifying an increase in security policies, for instance the exacerbation of repatriation policies mainly targeting Romanian Roma in 2007 in Italy was justified on the base of the threat constituted by Roma camps. Moreover, the Roma camps, from being a tool for rehousing people in need became a tool of the local government for sharing favors and bribes with part of its constituencies, for securing alliances and political compliance and the consensus of the electorate. This strong proximity to the political and NGO's fields through mechanisms of corruption, brokerage and coalition building made the Roma camps and their architecture resistant to the attacks of the challenging actors.

\section{A persistent architecture based on action fields of invisible relations}

The persistence of the Roma camps as architectural form concerns the regulation of social services in Rome and their system of incentives and regulation for the coordination of its actors. These latter belong to a strategic field of action whereby the political profits are linked to clientelism and electoral dynamics. These two components are different but they both converge into an institutional matrix that allocates the resources leading to the reproduction of the camp. At the same time, the internal actors of this strategic field do not develop demands for change and towards the integration and empowerment of the Roma. An incumbent mode of composing barriers, distribution of objects, permanence and symbolic order produces the Roma camps architectures. It is partially challenged by informal settlements, or by peripheral experience of more effective, community-based sheltering, but with no impact on the main dimension of Roma camps architectures: their borders, objects distribution, spatial organization and symbolic order have persisted despites criticism, political shifts, international denunciations. 
The analysis of the effects of the material barriers of the camps, which translate into the control of dissent, and of the mechanisms through which the camp creates several thresholds that enable its persistence, shows how the enduring exclusionary architectural form of the camp can be explained only by looking at the (power) relations within and among the action fields. As Pierre Bourdieu (2015) stated, the sociological study of reproduction and persistence in not based on the observation of visible interactions, but on the analysis of invisible relations (also Le Galès, 2001, for a more Weberian approach to invisible relations within contextualized urban policy sectors).

Indeed, merely promoting an upgrade of the physical facilities of the camps, with a more inclusive and economically sustainable design, is not enough to overcome this persistent exclusionary spatial arrangement. A similar reflection was already developed by the so-called de-institutionalization movements in the mental health sector, which denounced the sociological impossibility of improving the outcomes of psychiatric hospital by changing their internal facilities (Basaglia, 1987; Vitale 2010). Likewise, it is not enough to denounce how the current architecture feeds into the process of constant marginalization of this historically disenfranchised minority. The reasons for the architectural stability of the camp, and the persistence of this policy, need be sought in the political and economic relations among institutional and non-institutional actors and their strategies to maintain their dominant position, which in a vicious cycle are enabled through the camps' architecture. To change the latter, the former should change too.

Although it is probably too early to draw some conclusions on the possibility of change of the Roma camps in a near future, there are signs that confirm that to assail the economic and political interests enabled by the camps could be an effective de-stabilizing strategy. Following the scandal Mafia Capitale a series of third-sector associations historically working in the Roma camps have decided to boycott the recent public tender for subcontractors in the Roma camps with the intention to denounce the current management of the camps too focused on security and surveillance services, as well as on the ethnic profiling of the camps beneficiaries, to the detriment of inclusive social interventions. This initiative, which has increasingly being joined by several associations, is directly tackling the corrupted and political system sustaining the Roma camps, and its stability will depend on the strategies that the opponents to the Roma camps will develop to enlarge the Roma advocacy coalition as well as on how the dominant groups will deal with them.

\section{References}


Aguilera, T., \& Vitale, T. (2015). Bidonvilles en Europe, la politique de l'absurde. Revue Projet, 348, 68-76. doi: $10.3917 /$ pro.348.0068.

Anzaldi, A., \& Stasolla, C. (2010). Esclusi e Ammassati. Rapporto di ricerca sulla condizione dei minori rom nel villaggio attrezzato di via di Salone a Roma. www.21luglio.org. Accessed 1 July 2016.

Associazione 21 Luglio (2012). Diritti Rubati. Rapporto sulle condizioni di vita dei minori rom e delle loro famiglie nel 'villaggio attrezzato' si via della Cesarina a Roma. www.21luglio.org. Accessed 1 July 2016.

Associazione 21 Luglio (2014a). Campi Nomadi s.p.a. Segregare, concentrare e allontanare i rom. I costi a Roma nel 2013. www.21luglio.org. Accessed 1 July 2016.

Associazione 21 Luglio (2014b). Senza Luce. Le politiche della Giunta Marino, le comunità rom e sinte nella città di Roma e il 'Best House Rom'. www.21luglio.org. Accessed 1 July 2016.

Associazione 21 Luglio (2015). Centri di raccolta s.p.a. I centri di assistenza abitativa per soli rom. I costi a Roma nel 2014 e i percorsi per il loro superamento. www.21luglio.org. Accessed 1 July 2016.

van Baar, H. (2011). Europe's Romaphobia: Problematization, Securitization, Nomadization. Environment and Planning D: Society and Space, 29, pp. 203-212. doi: 10.1068/d2902ed1.

Bagnasco, A. (2016). La questione del ceto medio. Bologna: il Mulino.

Bachrach, P., \& Baratz, M.S. (1970). Power and Poverty: Theory and Practice. New York: Oxford University Press.

Basaglia, F. (1987). Psychiatry Inside Out. New York: Columbia University Press.

Berenice, Compare, Lunaria, \& OsservAzione (2013). Segregare costa. La spesa per $i$ 'campi nomadi' a Napoli, Roma e Milano. www.lunaria.org. Accessed 1 July 2016.

Boisseuil, C. (2016). Agence exécutive et reddition de compte. Revue Française d'Administration Publique.

Boltanski, L., \& Thévenot, L. (2006). On Justification. The Economies of Worth. Princeton:

Princeton University Press. 
Bonetti, P., Simoni, A., \& Vitale, T. (Eds.), La condirione giuridica di rom e sinti in Italia. Milan: Giuffré.

Bourdieu, P. (2015). Sociologie. Paris: Seuil.

Bravi, L., 2009. Tra inclusione ed esclusione. Una storia sociale dell'educazione dei rom e dei Sinti in Italia. Milan: Unicopli.

Brunello, P. (1996) (Ed.). L'urbanistica del disprezzo. Campi rom e società itliana. Rome: Manifestolibri.

Clough Marinaro, I., \& Daniele, U. (2014). A failed Roma revolution: Conflict, fragmentation and status quo maintenance in Rome. Ethnicities, 14(6), 775-792. doi: $10.1177 / 1468796814542181$.

Comune di Roma, 2011. Documento di sintesi Interventi per le popolazioni Rom', Allegato 7 - Allo schema del piano regolatore sociale 2011-2015.

Cremaschi, M., 2013. The Politics of Splintering. Research Notes on Immigrants and Urban Developments in Rome, Kolkata and Buenos Aires. Planum, 27 (2), pp. 39-49.

Cremaschi, M., \& Fioretti, C. (2016). Diversity and interculturalism, a critique and a defence. Going through multiethnic neighbourhoods in Rome. In M. Balbo (Ed.), The Intercultural City: Exploring an Elusive Idea (pp. 109-121). London: IB Tauris.

Dalla Zuanna, G. (2013). La popolazione in forte disagio abitativo in Italia. La condirione dei richiedenti asilo, dei rifugiati e dei Rom. Rome: Cittalia - ANCI.

Daniele, U. (2011). "Nomads" in the Eternal City. Local Policies and Roma Participation in the 'Emergency' Era. Géocarrefour, 86 (1), 15-23.

ECRI (2002). 2nd Report on Italy Adopted on the 22 June 2001. Strasbourg: ECRI.

European Roma Rights Center (2000). Campland. Racial segregation of Roma in Italy. www.errc.org. Accessed 1 July 2016.

European Roma Rights Center (2013). Italy. A Report by the European Roma Rights Center. Country Profile 2011-2012. www.errc.org. Accessed 1 July 2016. 
European Union Agency for Fundamental Rights (2009). Housing conditions of Roma and Travellers in the European Union. http:/ / fra.europa.eu. Accessed 1 July 2016.

Fligstein, N., \& McAdam, D. (2011). Toward a General Theory of Strategic Action Fields. Sociological Theory, 29(1), 1-26. doi: 10.1111/j.1467-9558.2010.01385.x

Fligstein, N., \& McAdam, D. (2012). A Theory of Fields. New York: Oxford University Press.

Halpern, C., Lascumes, P., \& Le Galès, P. (2014) (Eds.). L'instrumentation de l'action publique. Paris: Presses de Sciences Po.

Laino, G., Vitale, T. (2015). Abitare le contraddizioni, vincolare l'incrementalismo. Città e campi rom nell'Italia della crisi. Crios. Critica degli ordinamenti spaziali, 5(2), 23-32. doi: $10.7373 / 82133$.

Le Galès, P. (2001), Urban Governance and Policy Networks. Public Administration, 79(1), 167-184. doi: 10.1111/1467-9299.00251.

Maestri, G. (2014). The Economic Crisis as Opportunity: How Austerity Generates New Strategies and Solidarities for Negotiating Roma Access to Housing in Rome. City: analysis of urban trends, culture, theory, policy, action, 18(6), 808-823. doi: 10.1080/13604813.2014.962895.

Manzoni, C. (2016). Should I stay or should I go? Why Roma migrants leave or remain in nomad camps. Ethnic and Racial Studies. doi: 10.1080/01419870.2016.1201579.

Monasta, L. (2011). La condizione di salute delle persone rom e sinti nei campi nomadi. In Bonetti,

P., Simoni, A., \& Vitale, T. (Eds.), La condizione giuridica di rom e sinti in Italia. Milan: Giuffré.

Muzzonigro, A. (2011). Savorengo Ker. Urbanistica Informazioni, 238, 43-44.

Pasta, S. \& al. (2016). I cicli di segregazione e sgomberi a Milano. In T. Vitale (Ed.), Inchiesta sui campi rom. Florence: La casa Usher.

Però, D. (1999). Next to the Dog Pound: Institutional Discourses and Practices about Rom Refugees in Left-Wing Bologna. Modern Italy, 4(2), 207-224. doi: 10.1080/13532949908454830. 
Polizzi, E., Tajani, C., \& Vitale, T. (2013). Programmare i territori del welfare. Attori, meccanismi ed effetti. Rome: Carocci.

Regione Lazio, 1985. Legge Regionale 82/1985 'Norme in favore dei rom'.

Sampson, R. (2012). Great American City. Chicago: Chicago University Press.

Sibley, D. (1981). Outsiders in urban societies. New York: St. Martin’s Press.

Sigona, N. (2002). Figli del ghetto. Gli italiani, i campi nomadi e l'invenzione degli 'zingari'. Civezzano: Nonluoghi Libere Edizioni.

Sigona, N. (2003). How Can a 'nomad' Be a Refugee? Kosovo Roma and Labelling Policy in Italy. Sociology, 37(1), 69-80. doi: 10.1177/0038038503037001445.

Sigona, N. (2011). The governance of Romani people in Italy: discourse, policy and practice. Journal of Modern Italian Studies, 16(5), 590-606. doi: 10.1080/1354571X.2011.622468.

Sigona, N. (2015). Campzenship: reimagining the camp as a social and political space. Citizenship Studies, 19(1), 1-15. doi: 10.1080/13621025.2014.937643.

Silver, H., Scott, A., \& Kazepov, Y. (2010). Participation in Urban Contention and Deliberation. International Journal of Urban and Regional Research, 34(3), 453-477. doi: 10.1111/j.1468-2427.2010.00963.x.

Stasolla, C. (2012). Sulla pelle dei Rom. Roma: Edizioni Alegre.

Vitale T. (2009). Sociologia dos Conflitos Locais contra os Rom e os Sintos na Itália: pluralidade de contextos e variedade de instrumentos politicos, Revista Cidades. Comunidades e Terrritórios, 19, 65-80.

Vitale, T. (2010). Building a Shared Interest. Olinda, Milan: Social Innovation between Strategy and Organizational Learning. In F. Moulaert, \& al. (Eds.), Can Neighbourboods Save the City? Community Development and Social Innovation (pp. 81-92). London: Routledge.

Vitale, T. (Ed.) (2016). Inchiesta sui campi rom. Florence: La casa Usher. 
Vitale, T., \& Boschetti, L. (2011). Asymétries et tensions entre groupes Roms et associations «gadjé » à Milan”, in M. Berger, \& al. (Eds.), Du civil au politique. Ethnographies du vivre-ensemble (pp. 403-29). Bruxelles: P.I.E. Peter Lang.

Vitale, T., \& Claps, E. (2010). Not Always the Same Old Story: Spatial Segregation and Feelings of Dislike against Roma and Sinti in Large Cities and Medium-size Towns in Italy. In M. Stewart \& M. Rövid (Eds.), Multi-Disciplinary Approaches to Romany Studies (pp. 228-53). Budapest: CEU Press.

Vitale, T., \& Membretti, A. (2013). Just another roll of the dice: A socially creative initiative to assure Roma housing in North Western Italy. In F. Moulaert, et al. (Eds.), International Handbook on Social Innovation (pp. 186-196). Cheltenham: Edward Elgar,

Weaver, R.K. (1986). The politics of blame avoidance. Journal of Public Policy, 6(4), 371-398. doi: 10.1017/S0143814X00004219. 